\title{
KARAKTERISTIK KEPALA $K A L A$ DI SUMATRA: TINJAUAN ARKEOLOGI SENI \\ The Characteristics of Kala Head in Sumatra: Consideration of Art in Archaeology
}

\author{
Nainunis Aulia Izza' ${ }^{1)}$, Nurul Afni Sya'adah' ${ }^{2)}$, Melvidiani ${ }^{3)}$ \\ Program Studi Arkeologi, Universitas Jambi \\ Jalan Jambi--Muara Bulian Km 15, Mendalo Indah \\ E-mail: ${ }^{1)}$ nainunis@unja.ac.id (corresponding author) \\ ${ }^{2)}$ nurulafnisyaadah@gmail.com \\ ${ }^{3)}$ melvidianijbi789@gmail.com
}

\author{
Naskah diterima: 17 Juni 2020 - Revisi terakhir: 14 September 2020 \\ Disetujui terbit: 15 November 2020 - Tersedia secara online: 30 November 2020
}

\begin{abstract}
Kala head is a part of a temple, moreover in Java, Kala head is one of the common parts in Hindu-Buddhist temples. The problem was, there were differences on Java with other areas, Kala head in Sumatra were located not only in the lintel but also in other part of sacred objects. The purpose of this research was to discuss characteristic of Kala head in Sumatra based on its components and art styles. Based on the problem this research reveals characteristics of Kala head from Padanglawas, Padangroco, and South Sumatra. This research also discussed a comparative study of Kala head from Java, Southeast Asia (especially Khmer), and India. This research employed Archaeological Method ranging from observation, data gathering, analysis, and interpretation. The results showed Sumatra Kala head has different concept background. The dissimilarities contained in the different location, between a sacred building and sacred objects (stambha, stone base, and statue), different size, and decoration. Kala head in Sumatra is an independent figure without other figures (gods or makara) and other parts of bodies such as hand or claws on the Kala head from Sumatra. In conclusion, there were local Kala head art styles in Sumatra such as Padanglawas I, II, III, and Bumiayu.
\end{abstract}

Keywords: Bumiayu, art styles, Kala head, Padanglawas, Padangroco.

\begin{abstract}
Abstrak
Kepala Kala merupakan salah satu bagian candi, bahkan di Pulau Jawa kepala Kala merupakan komponen yang umum ada pada candi-candi Hindu ataupun Buddha dari masa Klasik Tua ataupun Klasik Muda. Permasalahannya adalah berbeda dengan yang ada di Jawa dan tempat lain, kepala Kala di Sumatra hanya ada di beberapa wilayah dan tidak selalu ditempatkan di atas ambang pintu bangunan suci. Penelitian ini bertujuan membahas karakteristik kepala Kala di Sumatra berdasarkan komponen-komponen dan gaya seninya. Untuk itu, pembahasan akan dilakukan terhadap kepala Kala dari Padanglawas, Padangroco, dan Sumatra Selatan, terutama Bumiayu. Pembahasan juga dilengkapi dengan perbandingan dengan kepala Kala yang ada di Jawa, Asia Tenggara (khususnya Khmer), dan India. Metode yang digunakan adalah metode arkeologi yang dilakukan dengan tahap observasi, pengumpulan data, analisis, dan interpretasi. Hasil penelitian sementara menunjukkan adanya perbedaan konsep gaya pemahatan kepala Kala antara Sumatra dan tempat-tempat lain yang terpengaruh Agama Hindu-Buddha. Perbedaan konsep tersebut antara lain diwujudkan dalam perbedaan lokasi pemahatan (pemahatan di bangunan berbilik dan objek sakral, seperti stambha, lapik, serta arca),
\end{abstract}


perbedaan ukuran, serta perbedaan hiasan kepala Kala yang di Sumatra tidak dilengkapi dengan figur lain (baik dewa maupun makara), serta ketiadaan bagian tubuh lain, seperti tangan atau kuku pada kepala Kala di Sumatra. Simpulannya adalah terdapat kepala Kala dengan gaya seni lokal yang ada di Sumatra, antara lain Padanglawas I, Padanglawas II, Padanglawas III, dan gaya seni Bumiayu.

Kata kunci: Bumiayu, gaya seni, kepala Kala, Padanglawas, Padangroco.

\section{PENDAHULUAN}

Tinggalan arkeologi masa Hindu-Buddha tersebar luas di Indonesia termasuk Pulau Sumatra. Keadaan geografis Sumatra yang termasuk dalam jaringan perdagangan internasional diperkirakan sudah ada jauh sebelum tahun masehi yang menjadi tempat yang strategis dalam persebaran budaya. Hampir seluruh bagian Pulau Sumatra pernah dipengaruhi oleh Hindu-Buddha, antara lain Sumatra Selatan dengan temuan Percandian Bumiayu yang terdapat di Kabupaten Penunggal Abab Lematang Ilir (PALI), Kawasan Cagar Budaya Muarajambi di Kabupaten Muaro Jambi, Situs Padang Roco di Kabupaten Dharmasraya, Candi Muara Takus di Provinsi Riau, hingga Kompleks Kepurbakalaan Padanglawas di Provinsi Sumatra Utara (Sedyawati et al., 2014). Situs percandian di atas merupakan situs-situs percandian utama dari masa Hindu-Buddha yang terdapat di Pulau Sumatra.

Candi adalah istilah dalam bahasa Indonesia yang merujuk kepada bangunan keagamaan tempat ibadah peninggalan purbakala yang berasal dari peradaban HinduBuddha. Bangunan ini digunakan sebagai tempat pemujaan para dewa ataupun memuliakan sang Buddha (Soekmono, 1974). Dalam istilah lokal, terutama di wilayah Sumatra bagian utara, candi juga disebut sebagai biaro. Candi memiliki beberapa bagian yang masing-masing memiliki arti yang berkaitan dengan ajaran Hindu-Buddha, misalnya konsep triloka, yakni pembagian candi berdasarkan dunia bawah, tengah dan atas atau bhurloka, bhuvarloka dan svarloka. Candi juga memiliki seni hias dekorasi yang mempunyai makna-makna tersendiri pada setiap bagiannya. Salah satu seni hias dekorasi pada candi adalah kepala Kala. Kepala Kala merupakan hiasan yang sering ditemukan pada ambang pintu candi. Pada candi-candi masa klasik tua umumnya Kala merupakan bagian tidak terpisahkan dari Makara dan disebut kala-makara (Basudewa \& Titasari, 2015: 178).

Pendeskripsian tentang seni Kala dan berbagai dekorasi lain pada pintu candi di Jawa, seperti makara dan singa, pernah dilakukan oleh E.B Vogler. Hasilnya menunjukkan terdapat perbedaan karakteristik pemahatan Kala dan unsur-unsur lain pada candi dari masa Jawa Tengah (yang selanjutnya disebut Klasik Tua) dan masa Jawa Timur (yang selanjutnya disebut Klasik Muda) serta daerah lain di luar Indonesia, seperti India, Champa, dan Kamboja (Vogler, 1949: 36). Melanjutkan penelitian Vogler, 
Soekmono dalam disertasinya juga menyetujui adanya perbedaan seni pada gaya candi Jawa Tengah dan Jawa Timur (Soekmono, 1974: 74--75). Pada candi Klasik Tua (sekitar abad ke-4--11 Masehi), kala-makara dipahat dengan ciri khas mulut menganga dan menyeramkan tanpa rahang bawah yang terletak di atas pintu candi dan terhubung dengan makara ganda di masing-masing tepi tangga, sedangkan pada langgam Klasik Muda (sekitar abad 12--16 Masehi), hanya kepala Kala yang menyeringai lengkap dengan rahang bawah yang terletak di atas pintu dan tidak berpasangan dengan makara.

Persebaran kepala Kala di Sumatra juga unik dan berbeda, khususnya apabila dibandingkan dengan persebaran kepala Kala di Jawa. Kepala Kala di Jawa dapat ditemui di sebagian besar candi, sedangkan di Sumatra hanya terdapat di beberapa tempat, antara lain Padanglawas, Simangambat, Padangroco, dan Sumatra Selatan, terutama Bumiayu. Di Kawasan Cagar Budaya Muarajambi (yang merupakan kawasan percandian terluas) sampai sekarang belum ditemukan sisa-sisa bangunan yang dilengkapi dengan kepala Kala. Adapun menurut Susetyo (2014: 107) terdapat kepala kala pada ujung makara Candi Kedaton, tetapi wajah figur tersebut lebih mirip ikan yang lazim menjadi unsur makara.

Selanjutnya, pembahasan mengenai kepala Kala sebagai salah satu jejak Tantrayana pernah disinggung oleh Sondang M. Siregar. Dalam pembahasan tersebut disebutkan bahwa kepala Kala yang ada di Bumiayu dan Arca Bhairawa dari Padang Roco merupakan salah satu unsur Tantrayana (Siregar, 2016: 21--22). Hal ini menunjukkan bahwa kepala Kala yang ditemukan di Sumatra memiliki bentuk dan posisi tata letak yang berbeda dengan Kala yang banyak ditemukan di Jawa. Perbedaan bentuk dan penempatan kepala kala di Sumatra kemudian memunculkan pertanyaan tentang bagaimana perbedaan bentuk dan penempatan kepala Kala di Jawa dan Sumatra?

Penjabaran mengenai kepala Kala di Sumatra belum pernah dilakukan secara eksplisit dan terperinci oleh para peneliti. Oleh karena itu, penjabaran persebaran kepala Kala yang terdapat di Sumatra belum dapat diketahui dengan jelas. Bahasan tentang perbedaan bentuk ataupun karakteristik yang secara visual sangat berbeda dengan Kala yang terdapat di Jawa maupun lainnya juga belum pernah dilaksanakan. Untuk itu, tulisan ini dibuat sebagai salah satu upaya untuk menganalisis karakteristik dan menyumbangkan interpretasi tentang Kala di Sumatra dari perspektif arkeologi seni. Berdasarkan permasalahan yang telah dikemukakan, tulisan ini akan membahas bagaimana persebaran Kala yang terdapat di Sumatra dan bagaimana karakteristik seni Kala di Sumatra dengan melakukan perbandingan terhadap kepala Kala yang ada di Jawa, Asia Tenggara, dan India. Kala yang diidentifikasi adalah Kala yang terdapat di Padanglawas, Simangambat, Padangroco, dan Sumatra Selatan, terutama Bumiayu. 
Semua Kala tersebar di Sumatra. Kala tersebar pada percandian dengan latar belakang keagamaan Hindu ataupun Buddha.

Penelitian ini menggunakan metode penalaran induktif, yaitu dilakukan dengan pengumpulan data, analisis, dan interpretasi (Mundardjito, 1986: 24-25). Sejalan dengan penalaran induktif yang dilakukan, metode yang digunakan adalah metode penelitian ikonografi oleh P. E. J Ferdinandus yang dilakukan dengan pendataan, pendeskripsian, identifikasi, pengomparasian, dan penarikan simpulan (Ferdinandus, 1978: 51--60). Data primer berupa kepala Kala yang terdapat di Sumatra yang tersebar di Padanglawas, Simangambat, Padangroco, dan Sumatra Selatan, terutama Bumiayu. Kemudian, data dilengkapi dengan data sekunder yang berasal dari laporan, artikel, peta sebaran situs, jurnal hingga foto ataupun gambar yang berhubungan dengan Kala. Data yang sudah terkumpul, kemudian dideskripsikan dan diidentifikasi. Hasilnya kemudian dianalisis. Tahap analisis dilakukan berupa analisis morfologi atau bentuk, analisis ini dilakukan guna mengetahui secara visual bentuk Kala yang terdapat di Sumatra. Setelah menganalisis Kala di Sumatra, kemudian data dikomparasikan dengan Kala yang berasal dari luar Sumatra. Setelah itu, dilakukan interpretasi terhadap seni kala di Sumatra, hasilnya didapatkan simpulan tentang karakteristik kala Sumatra (Gambar 1).

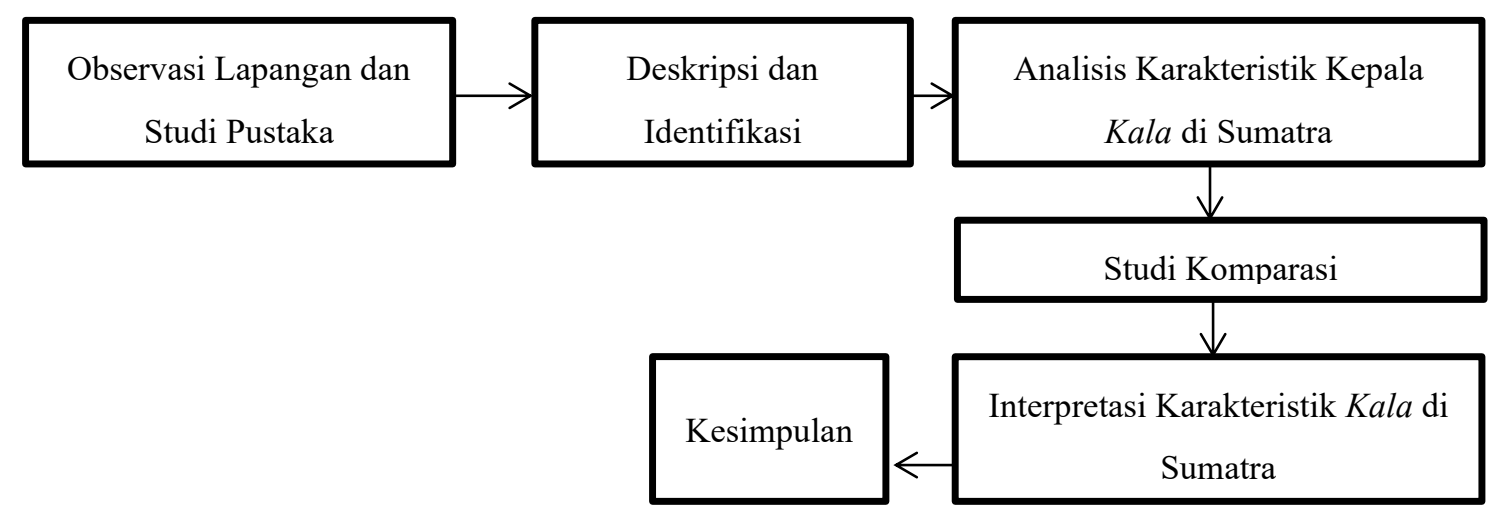

Gambar 1. Alur Penelitian (Sumber: Nainunis Aulia Izza dkk., 2020).

\section{HASIL DAN PEMBAHASAN}

\section{Mitologi dan Asal Usul Kepala Kala}

Dalam mitologi India digambarkan Kala Rahu. Kala Rahu merupakan tokoh raksasa yang muncul dalam cerita pencarian amrtha ketika pengadukan lautan susu oleh para dewa dan asura. Ketika amrtha telah ditemukan dan berhasil dikuasai oleh para dewa, para dewa akan membagikan dan meminum amrtha tersebut bersama-sama. Ketika amrtha tersebut dibagikan, seorang asura yang bernama Kala Rahu berhasil menyelinap dengan menyamar menjadi dewa agar memiliki kesempatan untuk dapat 
meminum amrtha tersebut. Kehadiran Kala Rahu diketahui dan dilaporkan oleh Dewa Surya dan Dewa Chandra kepada Dewa Wisnu, saat amrtha tersebut diminum oleh Kala Rahu Dewa Wisnu langsung melepaskan cakra untuk menebas leher Kala Rahu sehingga kepala dan badanya terputus. Kepala Kala Rahu yang telah diberkati amrtha akan selalu abadi, sedangkan badannya mati jatuh ke bumi. Kepala Kala Rahu tersebut dikisahkan membalas dendam kepada Dewa Surya dan Dewa Chandra ( Feller, 2004: 188; Basudewa \& Titasari, 2015: 180--181).

Kepala Kala di India, menurut Vajhacharya, sering disebut sebagai kirtimukha yang dapat diartikan sebagai wajah penuh kebanggan (Vajhacharya, 2014: 311). Kepala Kala merupakan sosok yang dapat ditemukan, baik pada bangunan Hindu, Buddha, maupun Jainisme di India dan Asia Tenggara. Telah disinggung pada paragraf sebelumnya bahwa mitologi kepala Kala erat kaitannya dengan Agama Hindu, khususnya aliran Saiwa, tetapi bukti tertua kepala Kala justru ditemukan pada situs Buddha di Bodhgaya. Pada perkembangannya, terutama masa pasca-gupta (Abad ke 7 sampai dengan 9 Masehi), Kala sering dipahatkan bersama dengan makara pada bagian kanan dan kirinya. Hal ini juga terjadi pada masa klasik tua, khususnya pada abad ke 8-10 Masehi di Jawa, Kala umumnya dilengkapi dengan makara (Hooykaas, 1956: 305-306).

Kepala Kala dalam kebudayaan India berkaitan erat dengan Vajrayana (disebut juga vajra-mastaka) dan aliran-aliran esoteris Hindu-Buddha, terutama pada masa Orissa. Fungsi utama penempatan kepala Kala pada bangunan suci tercantum pada kitab Purana. Dalam kitab Purana dijelaskan bahwa kepala Kala merupakan penjaga bangunan suci. Selain itu, kepala Kala juga digunakan sebagai topeng ritual dalam Agama Hindu aliran Saiwa (Agrawala, 1965: 258; Donaldson, 1976: 419). Dalam mitologi Bali terdapat berbagai versi Kala sebagai dewa dan Kala sebagai penunjuk waktu (Howe, 1984: 197). Kala sebagai dewa merupakan salah satu aspek dari Siwa dalam ajaran Hindu-Bali dan kadang-kadang juga sebagai pengganti Dewa Yama pada masa Jawa Kuno (Van Eerde, 1911: 31--32; Jordaan \& Acri, 2012: 295). Apabila ditarik garis merah antara mitologi Kala di India dan Bali agaknya Hindu-Bali lebih banyak memaknai kepala Kala sebagai bagian dari Siwa jika dibandingkan dengan Buddha atau Jainisme. Selain mitos Kala Rahu sebagai raksasa dan keberadaan kepala Kala tertua di Bodhgaya, nama Kala juga dimiliki oleh Mahakala yang biasanya diwujudkan dalam bentuk arca berpasangan dengan Nandiswara dalam candi-candi Hindu aliran Siwa (Rao, 1916). Pada artikel ini pembahasan akan difokuskan pada Kala yang didefinisikan sebagai Kepala Kala sebagai kirtimukha atau Kala Rahu pada kepurbakalaan Hindu ataupun Buddha di Sumatra. 


\section{Kepala Kala Kompleks Kepurbakalaan Padanglawas}

Temuan kepala Kala di Kompleks Kepurbakalaan Padanglawas agaknya memiliki jumlah yang paling banyak jika dibandingkan dengan tempat lain di Sumatra. Kepala Kala di Padanglawas antara lain ditemukan dalam bentuk fragmentaris, relief pada stambha, lapik, dan aksesoris arca. Pembahasan tentang kepala Kala di Padanglawas didasarkan pada Kala yang masih terdokumentasi hingga sekarang.

Fragmen kepala Kala di Padang Lawas pernah ditemukan di Sangkilon yang dalam laporan Schnitger disebut Aek Sangkilon. Menurut informasi dari Schnitger, fragmen Kala atau Banaspati dari Sangkilon berbahan batu, berukuran 35 x $63 \mathrm{~cm}$, dan ditemukan di sekitar bilik candi (Gambar 2). Berdasarkan deskripsi yang telah dilakukan, Kala dari Sangkilon memiliki ukuran yang relatif kecil apabila dibandingkan dengan kepala Kala yang ada di ambang pintu candi-candi di Jawa. Berdasarkan bentuk yang tersisa, terlihat kepala Kala menggambarkan raksasa yang memiliki mata melotot dan hidung besar, sedangkan bagian mulut dan rahangnya telah hilang (Schnitger, 1936: $1 \&$ 1937: 3).

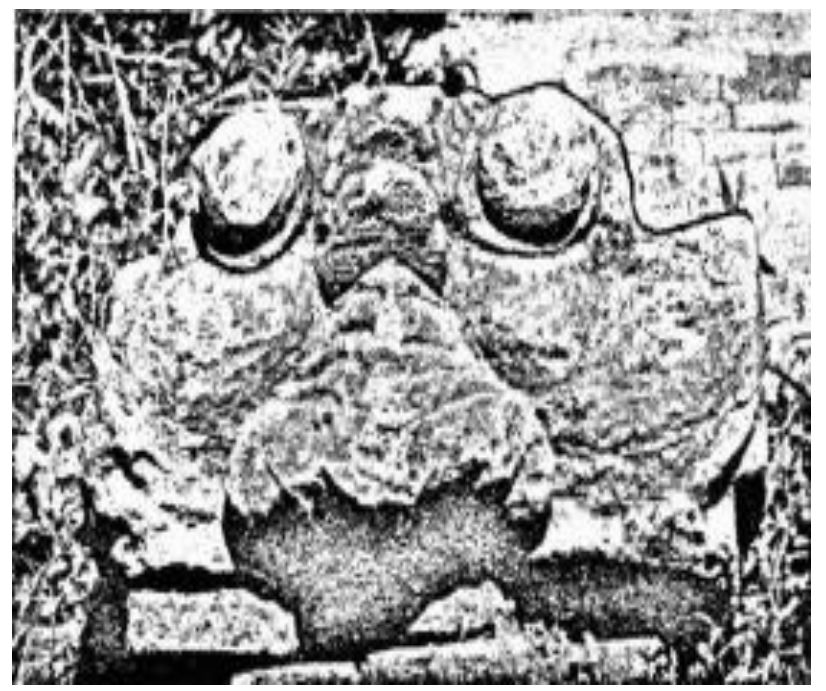

Gambar 2. Kala Biara Sangkilon (Sumber: Schnitger, 1937: PLATE XLI: 18).

Selanjutnya, kepala Kala di Padanglawas ditemukan di Kompleks Tandihat. Stambha pertama dari Tandihat memiliki relief kepala Kala yang mengelilingi tubuh stambha. Stambha ini sekarang disimpan di Museum Negeri Sumatra Utara. Relief kepala Kala pada stambha digambarkan dengan raut wajah menyeringai, melotot, dan tanpa rahang bawah (Gambar 3). Pada mulut Kala terdapat hiasan seperti untaian mutiara yang menjuntai dan bersambung sehingga membentuk rangkaian kepala Kala (Gambar 4). Bentuk untaian mutiara yang saling menyambung dari mulut Kala mirip dengan relief untaian pita yang ada pada bagian atap Bahal I (tetapi perlu penelitian khusus tentang hal ini) (Gambar 6 dan 7). Stambha kedua dari kompleks Tandihat juga memiliki 
pahatan beberapa kepala Kala yang mengelilingi kakinya. Figur Kala yang digambarkan menunjukkan wajah yang menyeringai dan mata melotot seperti halnya pada stambha pertama (Gambar 5). Selain pada dua stambha yang telah dijabarkan sebelumnya, menurut informasi dari Schnitger, di kompleks Tandihat juga pernah ditemukan kepala Kala kecil dan kepala Kala berukuran 23 x $26 \mathrm{~cm}$, tetapi Kala tersebut belum dapat dikonfirmasi ulang keberadaannya (Schnitger, 1937: 21).

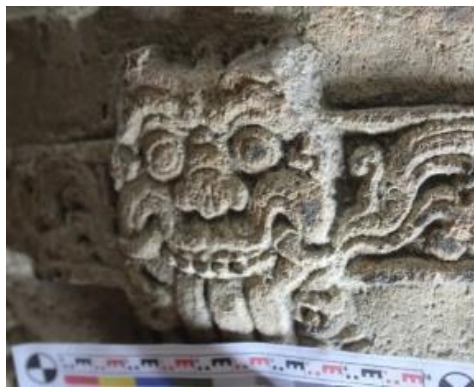

(3)

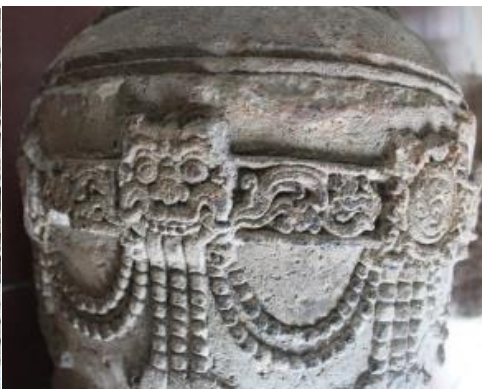

(4)

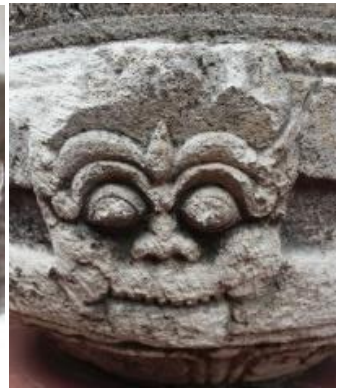

(5)

Gambar 3, 4, dan 5. Kala pada stambha dari Kompleks Tandihat, fragmen objek sakral koleksi Museum Negeri Sumatera Utara (Sumber: Dokumen Nurul Afni Sya'adah, 2019).

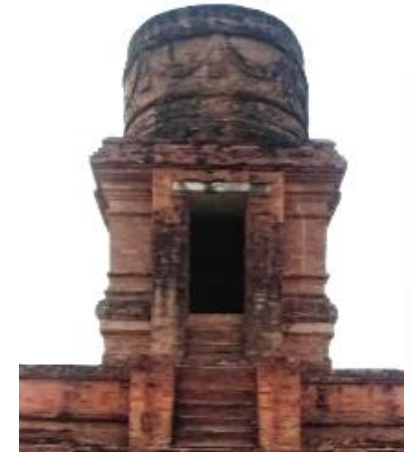

(6)

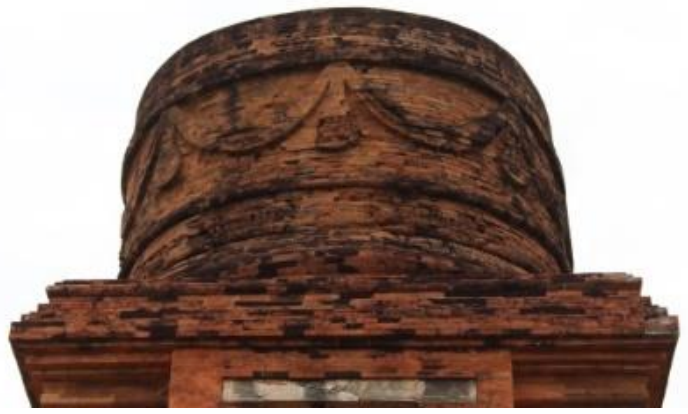

(7)

Gambar 6 dan 7. Relief untaian pita pada atap Bahal I (Sumber: Dokumen Nurul Afni Sya'adah, 2017; Nainunis Aulia Izza, 2020).

Situs ketiga di Padanglawas yang memiliki tinggalan pahatan kepala Kala adalah Sipamutung. Hiasan wajah atau Kepala Kala di Sipamutung terdapat pada kelat bahu arca (Susetyo, 2010: 29). Selain itu, menurut data dari Daniel Perret, juga terdapat fragmen kepala Kala yang diperkirakan dulu terpasang pada ambang pintu utama Sipamutung (Perret, 2014: 61). Kepala Kala pada kelat bahu arca dipahatkan pada bagian tengah lengan luar dan menggambarkan sosok yang menyeringai dengan mata melotot dan dilengkapi rahang bawah (Gambar 8). Bentuk muka Kala dari Sipamutung mirip dengan yang ditemukan di Tandihat (Gambar 5). 
Selanjutnya, pada Kompleks Bahal-Pulo, menurut informasi (Schnitger, 1937), pernah ditemukan beberapa pahatan Kala. Di Bahal III terdapat arca raksasa yang pada bagian depan dan belakang lapiknya dihias dengan pahatan kepala Kala triagonal, tetapi karena keadaan arca-arca dari Bahal III telah rusak, kepala Kala tersebut tidak dapat lagi ditelusuri. Di Pulo, Schnitger (1937: 27--29) juga pernah menyebutkan adanya hiasan kepala Kala yang ada pada dua tiang atau menara, tetapi kedua Menara tersebut juga hilang. Kepala Kala lain yang ada di Padanglawas berasal dari Bara (Gambar 9). Menurut deskripsi dari (Schnitger, 1937: 43), kepala Kala tersebut dipahatkan pada sebuah sandaran arca perunggu yang indah dan bergaya India Selatan. Sandaran arca sekarang disimpan di Museum Nasional (Restiyadi et al., 2011: 40). Selain kepala Kala, piagam perunggu tersebut dihias juga dengan dua makara dan halo.

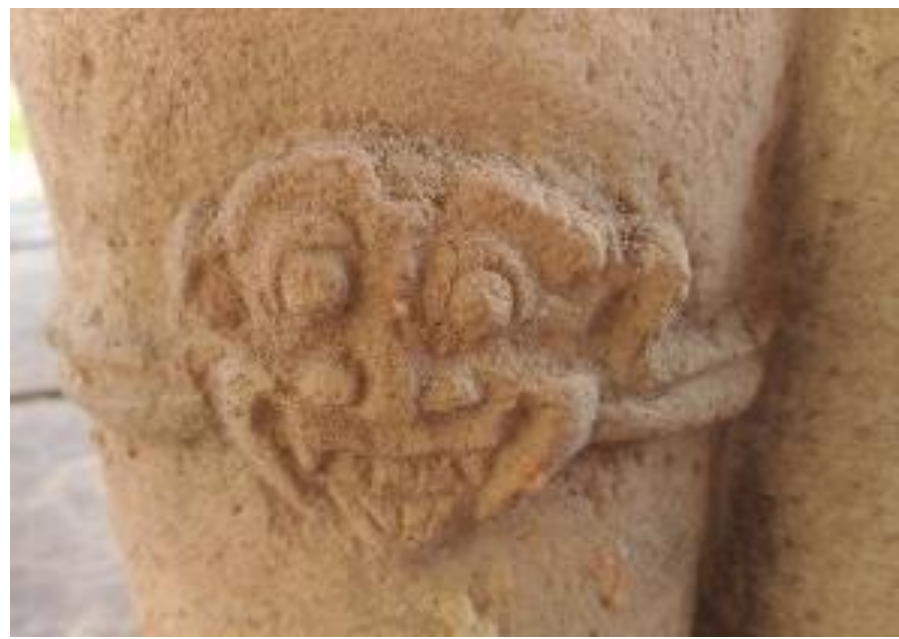

(8)

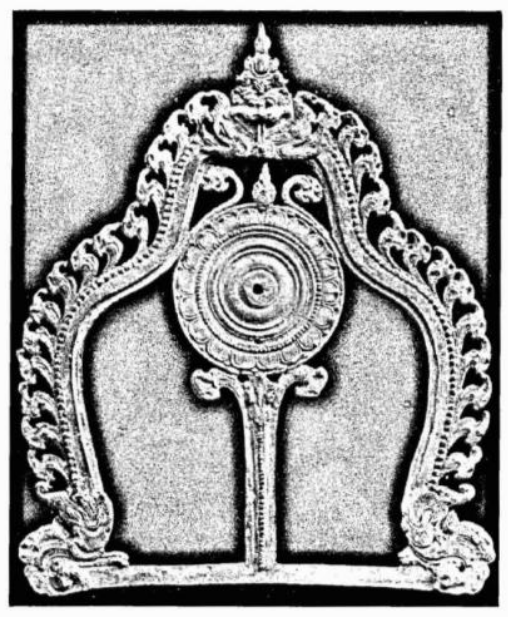

(9)

Gambar 8 dan 9. Kepala Kala pada kelat bahu fragmen arca di Sipamutung; sandaran arca perunggu berhias kepala Kala dari Bara (Sumber: Schnitger, 1937: PLATE XXXIV: 30; Dokumen Nainunis Aulia Izza, 2020).

Di kompleks Sitopayan, Nagasaribu, dan Padang Bujur juga terdapat berbagai pahatan kepala Kala yang ada pada lapik (Schnitger, 1937: 33). Kepala Kala dari tiga situs tersebut memiliki kesamaan pada raut muka yang menyeringai yang disertai dengan mata melotot, tetapi perbedaannya lebih menonjolkan taring dan seluruhnya dilengkapi dengan rahang bawah (Gambar 10, 11, dan 12). Karakteristik selanjutnya ketiga lapik ini ialah dipenuhi dengan berbagai motif teratai dan tumbuhan yang menunjukkan kesan bahwa kepala Kala tersebut merupakan figur utama yang ada di tengah-tengahnya. Lapik dari Nagasaribu memperlihatkan khusus mengenai kepala Kala ganda yang ada pada sisi atas dan sisi bawah lapik. 


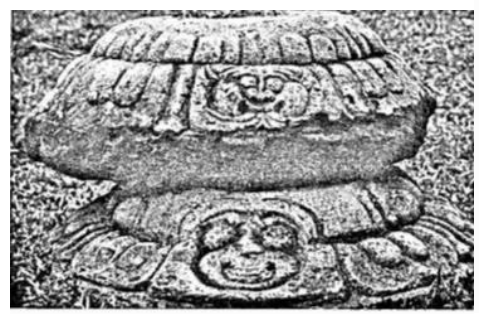

(10)

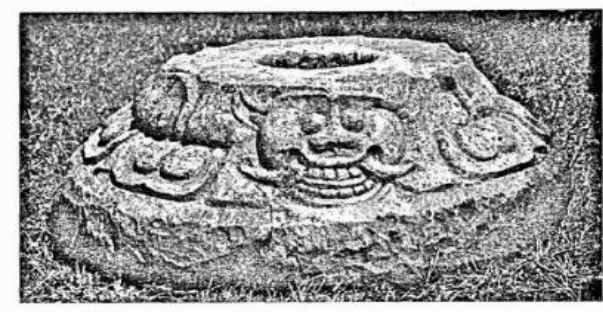

(11)

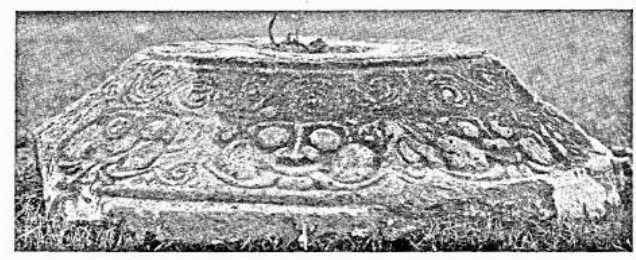

(12)

Gambar 10, 11, dan 12. Lapik berhias kepala Kala dari Nagasaribu, Sitopayan, dan Padang Bujur (Sumber: Schnitger, 1937: PLATE XXXIX: 31--33).

Selanjutnya, hiasan kepala Kala juga terdapat pada stambha dari Sisoldop dan Hodahoda. Stambha dari Sisoldop memiliki hiasan kepala Kala pada bagian kakinya (Gambar 13 dan 15). Bentuk kepala Kala-nya mirip dengan yang ada pada lapik dari Nagasaribu, Sitopayan, dan Padang Bujur, tetapi yang membedakannya adalah keberadaan telapak tangan, yaitu di antara kepala Kala dari Sisoldop, sedangkan kepala Kala pada stambha dari Hodahoda dipahatkan pada bagian atas stambha dan memiliki bentuk mirip dengan kepala Kala dari Tandihat yang digambarkan saling terhubung dengan hiasan mutiara yang menjuntai dari mulut kepala Kala (Gambar 4 dan 14).

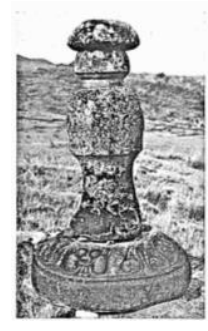

(13)

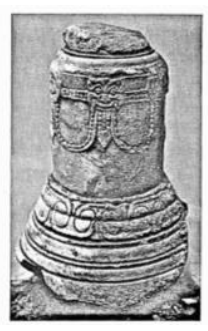

(14)

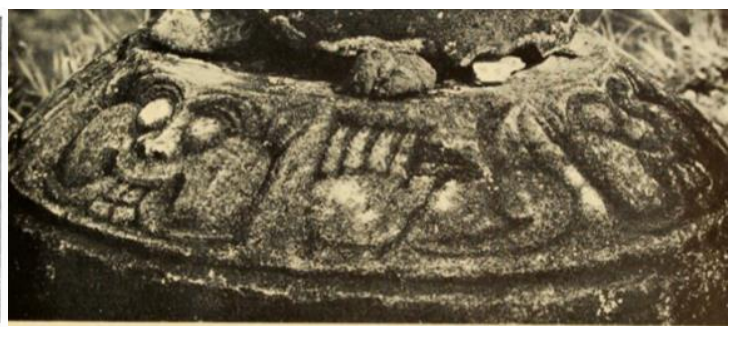

$(15)$

Gambar 13, 14, dan 15. Stambha dari Sisoldop (Kiri); Hodahoda (Tengah); Detail kepala Kala dari Sisoldop (Sumber: Schnitger 1936: PLATE IX \& 1937: PLATE XLII: 32--33).

Kepala Kala terakhir yang ada di Padanglawas pernah didata dari Situs Aek Haruaya atau Hayuara (Mulia, 1980: 18; Restiyadi et al., 2011: 31--32). Kepala Kala dari Situs Aek Haruaya berada pada badan stambha dan dilengkapi dengan pahatan manusia dengan berbagai pose (Gambar 16). Kepala Kala dari situs ini digambarkan memiliki 
rahang bawah dan keempat kepala Kala satu sama lain terhubung dengan untaian mutiara. Stambha sekarang sudah hilang.

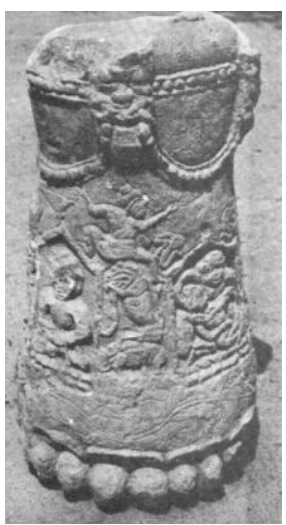

(16)

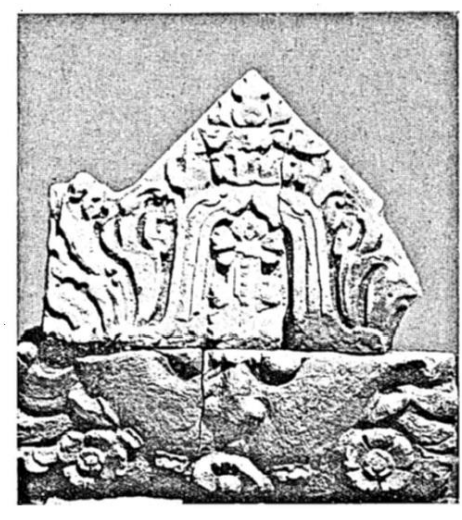

(17)

Gambar 16 dan 17. Kepala Kala pada tubuh stambha, kepala Kala dan batu berhias dari Simangambat (Sumber: Schnitger, 1937: 15; Mulia, 1980: 19).

Berdasarkan penjabaran yang telah dilakukan, hiasan kepala Kala yang berasal dari Padanglawas berada di atas pintu candi atau bangunan berbilik serta dipahatkan sebagai hiasan pada stambha, lapik, dan aksesoris arca. Hal ini mengindikasikan perbedaan konsep tentang penempatan kepala Kala sebagai objek sakral. Maksudnya adalah, baik di Jawa maupun Padanglawas, sesuai dengan penelitian Vogler dan Schnitger, kepala Kala sama-sama berasosiasi dengan bangunan sakral, baik itu biara, candi, maupun bukit yang disucikan. Perbedaannya adalah di Jawa kepala Kala, baik yang berbahan batu maupun bata ditempatkan di atas ambang pintu. Jadi, ketika seseorang masuk ke dalam ruang utama candi, seolah-olah ia disambut oleh kepala Kala (Vogler, 1949: 14), sedangkan di Padanglawas kepala Kala dapat diletakkan pada ambang pintu ataupun sebagai relief pada objek sakral.

Berdasarkan ukurannya, kepala Kala dari Jawa memiliki ukuran lebih besar apabila dibandingkan dengan yang ada di Padanglawas. Fenomena ini sekaligus mengindikasikan urgensi stambha dalam konteks bangunan suci di Padanglawas. Kuat dugaan bahwa beberapa bangunan suci di Padanglawas merupakan bangunan tidak berbilik dan objek pemujaan utamanya adalah stambha. Jika ditinjau berdasarkan gaya pemahatannya, kepala Kala dari Padanglawas yang masih dapat ditelusuri dan/atau didokumentasikan memiliki tiga gaya. Pertama, kepala Kala tanpa juntai dan taring, seperti yang berasal dari Sangkilon, salah satu stambha dari Tandihat, kelat bahu arca dari Sipamutung, dan piagam perunggu dari Bara. Gaya kedua adalah kepala Kala dengan untaian tali mutiara mirip dengan hiasan pada atap Bahal I. Kepala Kala gaya kedua ini berasal dari Tandihat, Hodahoda, dan Aek Haruaya. Meskipun tidak memiliki rahang bawah yang mirip dengan kepala Kala masa klasik tua, berdasarkan penanggalan 
relatif situsnya, Tandihat merupakan situs dari masa klasik muda (sekitar abad ke-12 masehi) yang dibuktikan dengan adanya prasasti dari abad ke-12 (Sedyawati et al., 2014: 34). Ketiga, adalah gaya kepala Kala yang mengekspos taring. Gaya kepala Kala ini umumnya berada pada bagian bawah objek sakral, seperti yang terdapat pada Situs Sitopayan, Padang Bujur, dan Sisoldop.

\section{Kepala Kala Simangambat}

Menurut informasi Schnitger (1937: 14) terdapat dua fragmen kepala Kala dari Simangambat. Simangambat adalah situs yang bernapas Hindu-Saiwa yang terletak di Mandailing Natal, Sumatra Utara. Kepala Kala dari Simangambat terbuat dari batu dan tidak memiliki rahang bawah (Gambar 17). Apabila dibandingkan dengan kepala Kala dari Padanglawas, Padangroco, dan Bumiayu bentuk mukanya cenderung lebih pipih. Tidak diketahui pasti penempatan kepala Kala tersebut pada candi karena keadaan candi yang tinggal puing. Jika ditinjau dari gaya seninya, sesuai dengan penelitian Vogler (1949), Kala digambarkan dengan komponen yang tidak lengkap, tanpa rahang bawah, telinga dan tangan. Mahkota Kala berbentuk segitiga dengan hiasan flora pada bagian tengahnya. Tanduk digambarkan melengkung ke arah dalam, mulai dari bola mata sampai dengan mahkota, mata digambarkan bulat melotot dengan detail penggambaran biji dan pupil mata sehingga dapat diketahui bahwa arah pandangan mata Kala ke bawah sehingga tidak terlihat adanya lubang hidung dan tulang hidung yang digambarkan besar, pipi digambarkan sempit, seolah-olah menyatu dengan bibir. Mulut Kala membuka lebar, memperlihatkan deretan gigi yang berbentuk persegi dengan ukuran besar. Pada bagian bawah deretan gigi terdapat hiasan bermotif sulur-suluran. Teknik pahatan yang digunakan memberikan kesan datar (dua dimensi). Kepala Kala dari Simangambat termasuk gaya Jawa Tengah atau Klasik Tua, sedangkan berdasarkan penelitian yang telah dilakukan oleh (Restiyadi, 2010: 6) kepala Kala Simangambat berasal dari sekitar abad ke 9--11 Masehi atau masih tergolong masa klasik tua. Fragmen kepala Kala yang ditemukan merupakan fragmen bagian ambang pintu yang terbuat dari batu pasir (sandstone) (Taim, 2010: 35). Berdasarkan keletakan dan ukurannya, kepala Kala dari Simangambat memiliki kemiripan dengan kepala Kala yang ada di Jawa, yaitu ditempatkan di atas ambang pintu bangunan suci (candi) berbilik.

\section{Kepala Kala Padangroco}

Satu-satunya tinggalan kepala Kala yang telah ditemukan dari Padangroco adalah pahatan kepala Kala pada busana Arca Bhairawa. Dugaan tentang keberadaan kepala Kala lain di Sumatra Barat dapat dilacak dari lambang pada prasasti-prasasti 
Adityawarman. Lambang atau lencana pada prasasti-prasasti Adityawarman menunjukkan figur yang distilir, didominasi sulur-suluran, bonggol, dan penggambarannya tidak konsisten sehingga belum dapat dipastikan apakah lambang tersebut menggambarkan Kala atau ornamen lain karena mirip juga dengan figur bertaring candrakapala yang digunakan sebagai lambang Kerajaan Kadiri masa Bameswara (Istiawan, 2006; Kuswanto, 2009) Untuk itu, perlu dilakukan kajian tersendiri yang lebih mendalam tentang figur yang dipahatkan pada lencana prasastiprasasti Adityawarman. Berkaitan dengan hal tersebut pembahasan pada tulisan ini hanya difokuskan pada kepala Kala Padangroco.

Pahatan kepala Kala terletak pada sabuk atau ikat pinggang yang seolah-olah menempel pada baju yang menutupi pinggang hingga lutut arca (Gambar 18). Bentuk kepala Kala cukup raya dengan hiasan untaian mutiara yang ada di samping kanan, kiri, serta menjuntai dari mulut Kala. Pemahatan kepala Kala tidak dilengkapi dengan rahang bawah. Selain di Padangroco, pemahatan kepala Kala yang berkaitan dengan Bhairawa juga terdapat di Ellora, India yang berasal dari abad ke-10 (Stein, 2018: 182). Hal ini menunjukkan bahwa terdapat kesamaan konsep tentang Kala yang erat hubungannya dengan Tantrayana di Sumatra dan India. Jika ditinjau berdasarkan kronologi relatif arca serta temuan di sekitarnya, Arca Bhairawa dari Padangroco berasal dari abad ke-13 atau masa Singhasari yang menandai kuatnya pengaruh Tantrayana secara nyata di Nusantara. Hal ini sekaligus menunjukkan eratnya hubungan politik antara penguasa di Singhasari dan Padangroco (Hardiati et al., 2010: 439--440). Gaya kepala Kala-nya juga mirip dengan yang ada di Padanglawas (gaya pertama).

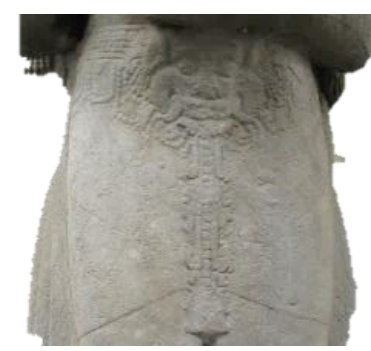

Gambar 18. Kepala Kala pada Arca Bhairawa dari Padangroco (Sumber: Koleksi Museum Nasional, Dokumen Nainunis Aulia Izza, 2017).

\section{Kala dari Palembang, Bingin Jungut, dan Percandian Bumiayu}

Kepala Kala di Sumatra Selatan ditemukan di Palembang, Bingin Jungut, dan Percandian Bumiayu. Di Palembang, menurut data dari (Schnitger, 1937: 4), pernah ditemukan tiga kepala Kala yang terdiri atas sebuah fragmen kepala Kala besar (tersisa bagian kanan) dan 2 kepala Kala kecil yang dipahat dengan indah (Gambar 19, 20, dan 21). Untuk kepala Kala di Palembang, belum ditemukan data lebih lanjut mengenai gaya seninya. Selanjutnya, kepala Kala dari Bumiayu tidak seperti kepala Kala lain 
yang mayoritas berbahan batu. Kepala Kala dari Bumiayu terbuat dari terakota. Bentuk kepala Kala di Bumiayu umumnya berwajah bulat dan dilengkapi dengan mata melotot, hidung besar, serta mulut tersenyum menyeringai. Kepala Kala dari Bumiayu cenderung digambarkan sebagai figur tunggal dan pahatan detailnya hanya terdapat pada bagian atas mata. Serupa dengan Kala dari Bumiayu, terdapat temuan lepas kepala Kala dari sekitar Bingin Jungut (Gambar 22). Jika ditinjau berdasarkan gaya pemahatannya, kepala Kala dari Bumiayu dan sekitar Bingin Jungut memiliki karakteristik tersendiri yang dalam tulisan ini disebut gaya Bumiayu. Penempatan Kala pada bangunan suci tidak diketahui karena Kala sudah dipindahkan ke ruang koleksi Percandian Bumiayu.

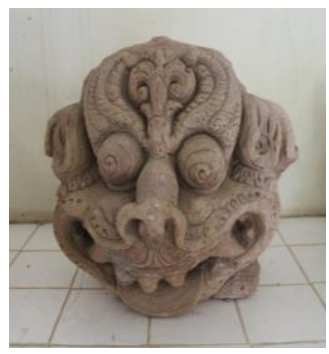

(19)

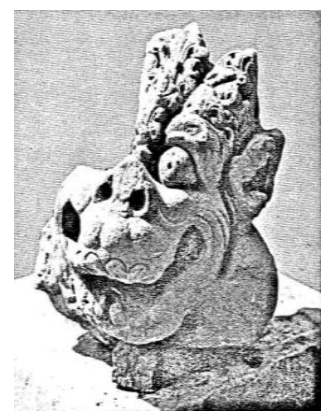

(21)

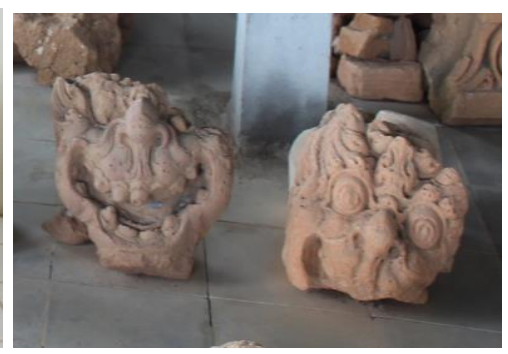

(20)

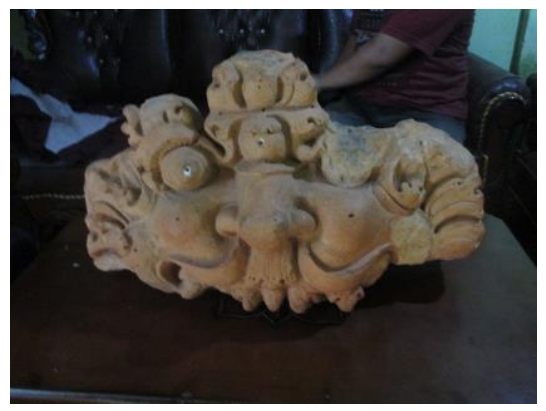

(22)

Gambar 19, 20, 21, 22. Kepala Kala di Percandian Bumiayu (atas dan kiri bawah) dan kepala Kala dari sekitar Bingin Jungut (Sumber: Schnitger, 1937: PLATE III: 18 \& Dokumen Nurul Afni Sya'adah, 2017, Nainunis Aulia Izza, 2020).

\section{Karakteristik Kepala Kala di Sumatra}

Berdasarkan penjabaran dan analisis yang telah dilakukan terhadap kepala Kala dari berbagai tempat di Sumatra, terdapat berbagai karakteristik gaya seni pada masingmasing wilayah (Tabel 1). Lebih dalam lagi, pada subbab ini akan dianalisis karakteristik kepala Kala di Sumatra yag dibandingkan dengan kepala Kala dari Jawa, Asia Tenggara, serta India. Sesuai dengan penelitian tentang pembagian gaya kepala Kala yang pernah dilakukan oleh E. B Vogler, kepala Kala di Sumatra, kecuali dari Simangambat, memiliki gaya pemahatan yang jauh berbeda, baik dengan gaya Dieng, Sailendra, Jawa Tengah akhir maupun gaya Jawa Timur (Vogler, 1949). Apabila dibandingkan dengan kepala Kala dari luar Indonesia, baik itu dari Asia Tenggara 
(Khmer) maupun India kepala Kala di Sumatra memiliki gaya yang berbeda pula. Selain perbedaan variasi penempatan dan jumlah kepala Kala pada sebuah objek sakral, seperti yang telah disinggung pada subbab Padanglawas, terdapat setidaknya tiga perbedaan, antara lain dari segi ukuran, bagian tubuh dan figur pelengkap, serta hiasan.

Perbedaan ukuran kepala Kala di Sumatra dan luar Sumatra berkaitan erat dengan ukuran dan penempatannya. Kepala Kala di Sumatra, terutama dari Padanglawas memiliki ukuran yang lebih kecil daripada kepala Kala dari Jawa dan India karena ditempatkan pada objek yang lebih kecil (bukan bangunan yang besar). Mengenai kepala Kala dari Bumiayu, berdasarkan ukurannya, juga lebih kecil apabila dibandingkan dengan kepala Kala dari Jawa dan India, sedangkan kepala Kala dari Khmer yang umumnya ditempatkan pada lintel (ambang pintu) juga berukuran kecil yang disebabkan padatnya hiasan di sekitarnya. Berdasarkan bagian tubuh dan figur pelengkapnya, kepala Kala di Sumatra memiliki ciri khas yang lebih sederhana. Kepala Kala di Sumatra umumnya dipahatkan sebagai makhluk tunggal tanpa jari tangan (kecuali kepala Kala dari Sisoldop), dan figur pelengkap lain, seperti dewa-dewa, dwarapala, dan makara. Hal ini sangat berbeda apabila dibandingkan dengan kepala Kala di tempat lain. Pertama, kepala Kala masa Klasik Tua dari Candi Morangan yang dilengkapi dengan dua dwarapala dan jari di kanan dan kirinya (Gambar 23). Kedua, kepala Kala klasik muda dari Candi Kalicilik dan Candi Sawentar yang juga memiliki dua telapak tangan di kanan dan kirinya (Gambar 24 dan 25). Ketiga, kepala Kala dari Khmer dan India yang masing-masing dilengkapi dengan figur dewa-dewi pada bagian atas dan bawahnya (Gambar 26 dan 27). Mengenai hiasan ambang pintu bangunan suci dari Kamboja, khususnya era Khmer, terdapat berbagai variasi, di antaranya yang hanya dilengkapi dengan kepala Kala, kepala Kala beserta figur dewa-dewi, dan ambang pintu tanpa kepala Kala yang dihias dengan sulur-suluran serta figur dewa-dewi (Marcus, 1968: 323--325).

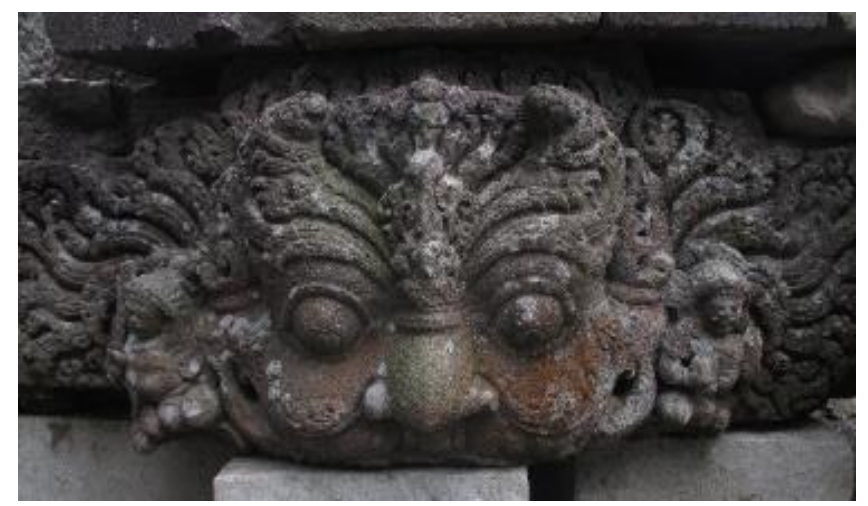

Gambar 23. Kepala Kala Candi Morangan dengan dua figur dwarapala di atas tangan kanan dan kiri (Sumber: Dokumen Nainunis Aulia Izza, 2017). 
Tabel 1. Perbandingan Kepala Kala

\begin{tabular}{|c|c|c|c|c|c|c|c|c|c|}
\hline \multirow[t]{2}{*}{ No } & \multirow{2}{*}{\multicolumn{2}{|c|}{ Asal }} & \multicolumn{7}{|c|}{ Aspek Perbedaan } \\
\hline & & & $\stackrel{\frac{\pi}{*}}{\Sigma}$ & 羿 & 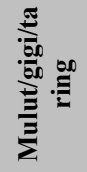 & 芫 & 预 & 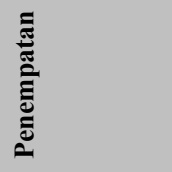 & : \\
\hline \multirow[t]{9}{*}{1.} & \multirow{9}{*}{$\begin{array}{l}\text { Kepurbakalaa } \\
\mathrm{n} \\
\text { Padanglawas }\end{array}$} & Sangkilon & Melotot & Besar & Ada & - & - & - & Sedang \\
\hline & & Tandihat & Melotot & Besar & Ada & - & - & Stamba & Kecil \\
\hline & & Sipamutung & Melotot & Besar & Ada & Ada & - & $\begin{array}{l}\text { Kelat bahu } \\
\text { arca }\end{array}$ & Kecil \\
\hline & & Bara & Melotot & Besar & Ada & Ada & - & $\begin{array}{l}\text { Sandaran arca } \\
\text { perunggu }\end{array}$ & Kecil \\
\hline & & Nagasaribu & Melotot & Besar & Ada & Ada & - & Stamba & Kecil \\
\hline & & Sitopayan & Melotot & Besar & Ada & Ada & - & Stamba & Kecil \\
\hline & & Padang Bujur & Melotot & Besar & Ada & Ada & Ada & Stamba & Kecil \\
\hline & & Sisoldop & Melotot & Besar & Ada & Ada & Ada & Stamba & Kecil \\
\hline & & Haruaya & Melotot & Besar & Ada & Ada & - & Stamba & Kecil \\
\hline 2. & Simangambat & & Melotot & Besar & Ada & Ada & - & - & Sedang \\
\hline \multirow[t]{2}{*}{3.} & $\begin{array}{l}\text { Sumatra } \\
\text { Barat }\end{array}$ & Padangroco & Melotot & Besar & Ada & - & - & $\begin{array}{l}\text { Sabuk Arca } \\
\text { Bhairawa }\end{array}$ & Kecil \\
\hline & & $\begin{array}{l}\text { Prasasti-prasasti } \\
\text { Adityawarman (?) }\end{array}$ & $\begin{array}{l}\text { Melotot, } \\
\text { ada juga } \\
\text { yang tidak } \\
\text { dilengkapi } \\
\text { mata }\end{array}$ & $\begin{array}{l}\text { Besar, } \\
\text { ada juga } \\
\text { yang } \\
\text { tanpa } \\
\text { hidung }\end{array}$ & Ada & $\begin{array}{l}\text { Disti } \\
\text { lir }\end{array}$ & - & Prasasti & Kecil \\
\hline 4. & \multicolumn{2}{|l|}{ Muara Jambi (?) } & Melotot & Kecil & Ada & Ada & - & Ujung makara & Kecil \\
\hline \multirow[t]{2}{*}{5.} & Bumiayu & & Melotot & Besar & Ada & Ada & - & - & Sedang \\
\hline & Bingin Jungut & & Melotot & Besar & Ada & - & - & - & Sedang \\
\hline 6. & Klasik Tua & Candi Morangan & Melotot & Besar & Ada & - & Ada & $\begin{array}{l}\text { Ambang } \\
\text { Pintu }\end{array}$ & Besar \\
\hline 7. & Klasik Muda & $\begin{array}{l}\text { Candi Kalicilik } \\
\text { dan Candi } \\
\text { Sawentar }\end{array}$ & Melotot & Besar & Ada & Ada & Ada & $\begin{array}{l}\text { Ambang } \\
\text { Pintu }\end{array}$ & Besar \\
\hline 8. & $\begin{array}{l}\text { Kala Khmer } \\
\text { dan India }\end{array}$ & & Melotot & Besar & Ada & Ada & Ada & $\begin{array}{l}\text { Ambang } \\
\text { pintu }\end{array}$ & Kecil \\
\hline
\end{tabular}

(Sumber: Nainunis Aulia Izza, dkk).

Berdasarkan kepadatan hiasannya, kepala Kala dari Sumatra lebih sederhana, terutama dibandingkan dengan yang ada di Khmer. Kepala Kala di Khmer dipahatkan seolaholah sebagai bagian sentral dari lintel, tetapi di sekitarnya terdapat ukiran naga yang berbentuk sulur-suluran yang dilengkapi dengan hiasan padat. Selain terdapat tiga perbedaan, kepala Kala dari Sumatra, Jawa, Asia Tenggara (Khmer), dan India memiliki dua persamaan. Persamaan tersebut antara lain berasal dari segi bahan dan raut muka. Berdasaran bahannya, kepala Kala yang ada umumnya dipahatkan pada batu dan ada pula yang dipahatkan pada bata, terakota, dan logam. Selanjutnya, seluruh kepala Kala memiliki mata melotot, hidung besar, dan mulut menganga yang menghasilkan raut muka menyeringai.

Mengenai periodisasi, kepala Kala di Sumatra agaknya tidak dapat disamakan dengan penanggalan relatif di Jawa (Klasik Tua dan Klasik Muda). Hal ini didasarkan 
pada perbedaan gaya pemahatan serta penempatan Kala di Sumatra yang tidak sama dengan Jawa ataupun tempat lain di luar Indonesia. Kuat indikasi kepala Kala dan kerajaan-kerajaan di Sumatra berkembang bersama dengan Jawa, tetapi memiliki gaya yang berbeda pada setiap wilayah. Hal ini sekaligus menunjukkan adanya gaya seni khas kepala Kala Sumatra, antara lain gaya seni Padanglawas I, Padanglawas II, Padanglawas III, dan gaya seni Bumiayu.

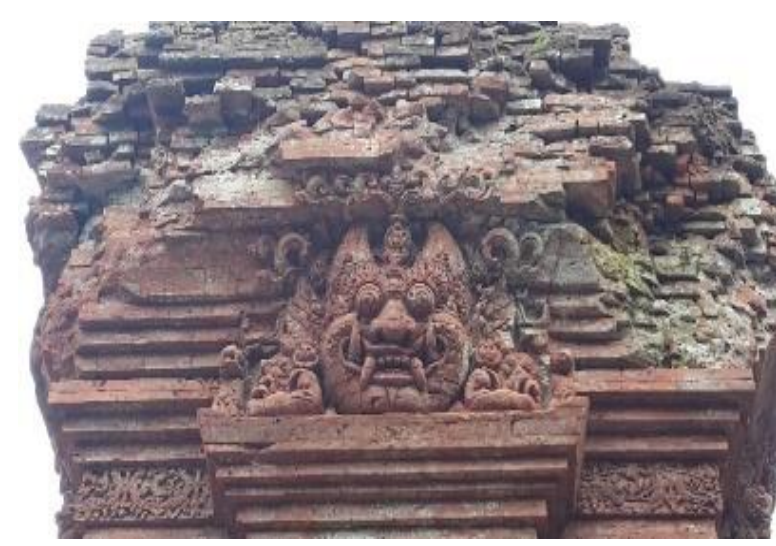

(24)

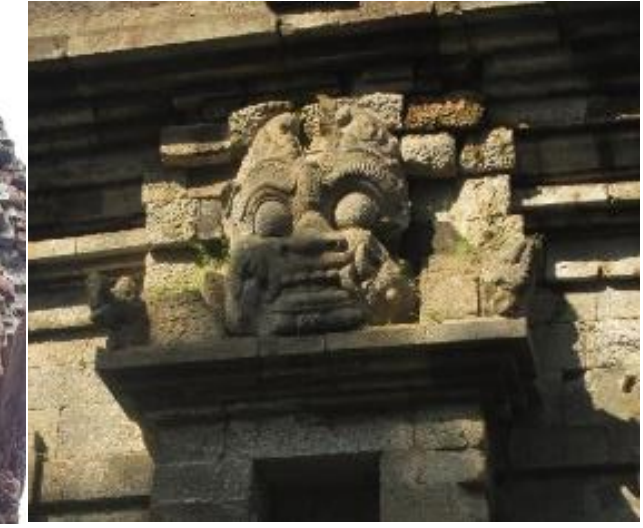

(25)

Gambar 24 dan 25. Kepala Kala berbahan bata dari Candi Kalicilik yang dilengkapi dengan tangan dan kepala Kala Candi Sawentar (Sumber: Dokumen Nainunis Aulia Izza, 2015).

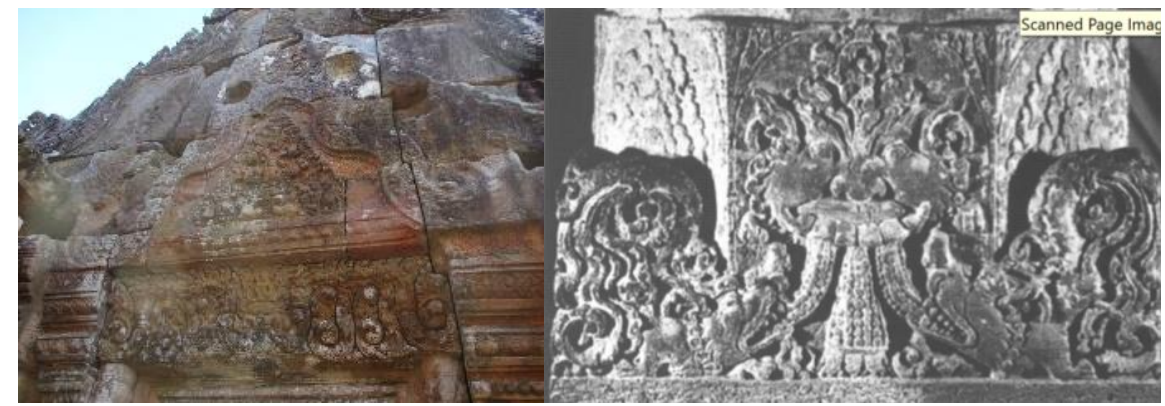

(26)

(27)

Gambar 26 dan 27. Dua kepala Kala dengan hiasan figur dewa-dewa pada lintel gaya Khmer di Preah Vihear, Kamboja (kiri) dan Kala-Makara pada Gua Ajanta I, India (kanan) (Sumber: Dokumen Nainunis Aulia Izza, 2016 \& Vajhacharya, 2014).

\section{SIMPULAN}

Berdasarkan pembahasan yang telah dilakukan terhadap karakteristik kepala Kala di Sumatra dapat dinyatakan bahwa terdapat perbedaan konsep gaya pemahatan kepala Kala antara Sumatra dan tempat-tempat lain yang terpengaruh Agama Hindu-Buddha. Perbedaan konsep tersebut antara lain diwujudkan dalam perbedaan media lokasi pemahatan (pemahatan di bangunan berbilik dan objek sakral, seperti stambha, lapik, serta arca), perbedaan ukuran, serta perbedaan hiasan kepala Kala yang di Sumatra yang 
tidak dilengkapi dengan figur lain (baik dewa maupun makara), serta ketiadaan bagian tubuh lain, seperti tangan atau kuku pada kepala Kala di Sumatra. Simpulannya adalah terdapat seni lokal kepala Kala yang ada di Sumatra, antara lain Padanglawas I, Padanglawas II, Padanglawas III, dan gaya seni Bumiayu.

Berkaitan dengan pembahasan mengenai kepala Kala, terdapat dua saran yang dapat diajukan. Pertama, penelitian tentang kepala Kala masih terbatas pada pembagian gaya kepala Kala di Jawa. Untuk itu, perlu dilakukan penelitian lebih baru dan mendalam tentang kepala Kala di Indonesia sebagai upaya untuk menggali variasi kepala Kala di seluruh Indonesia sekaligus untuk memperbarui hasil penelitian dengan menambahkan temuan-temuan baru. Kedua, perlu adanya penelitian terbaru yang menyeluruh tentang kepurbakalaan di Sumatra.

\section{DAFTAR PUSTAKA}

Agrawala, V. S. (2003). Studied in Indian Art. Varanasi: Vishwavidyalaya Prakashan.

Basudewa, D. G. Y., \& Titasari, C. P. (2015). Kesetaraan Ornamen Kala-Makara dengan Karang Bhoma: Studi Kasus Dalem Desa Taman Pohmanis. Forum Arkeologi, Vol $28,177-186$.

Donaldson, T. (1976). Development of the Vajra-Mastaka on Orissan Temple. East and West, Vol 26, 419-433.

Feller, D. (2004). The Sanskrit Efic's Representation of Vedic Myth. Delhi: Motial Banarsidass Publ.

Ferdinandus, P. E. J. (1978). Beberapa Metode Penelitian Ikonografi di Indonesia. Lokakarya Arkeologi, 51-60.

Hardiati, E. ., Djafar, H., Soeroso, Ferdinandus, P. E. ., \& Nastiti, T. . (2010). Sejarah Nasional Indonesia Jilid II: Zaman Kuno. Jakarta: Balai Pustaka.

Hooykaas, J. (1956). The Rainbow in Ancient Indonesian Religion. Bijdragen tot de Taal-, Land-en Volkenkunde, Vol 112, 291-322.

Howe, L. E. A. (1984). Gods, Spirits and Witches: The Balinese System of Person Definition. Bijdragen tot de Taal-, Land-en Volkenkunde, Vol 140, 193-222.

Istiawan, B. (2006). Selintas Prasasti dari Melayu Kuno. Batusangkar: Balai Pelestarian Peninggalan Budaya Batusangkar.

Jordaan, R., \& Acri, A. (2012). The Dikpalas of Ancient Java Revisited A New Identification for The Directional Deitis on The Siva Temple of The Loro Jonggrang Complex. Bijdragen tot de Taal-, Land- en Volkenkunde, Vol 168.

Kuswanto. (2009). Situs Besole: Sisa-Sisa Pintu Gerbang Dari Masa Kadiri. Berkala Arkeologi, 29(2), 43-54. https://doi.org/10.30883/jba.v29i2.378

Marcus, F. M. (1968). A Cambodian Sculptured Lintel. The Bulletin of The Cleveland Museum of Art, Vol 55, 321-330.

Mulia, R. (1980). The Ancient Kingdom and the ruins of Padang Lawas (North Sumatra). Berita Pusat Penelitian Arkeologi Nasional, No 14, 1-36.

Mundardjito. (1986). Metode Induktif-Deduktif dalam Penelitian Arkeologi di 
Indonesia. In Pertemuan Ilmiah Arkeologi IV (hal. 200-201). Jakarta: Pusat Penelitian Arkeologi Nasional.

Perret, D. (2014). The Sculpture of Padang Lawas: An Updated Inventory. In History of Padang Lawas North Sumatra II: Societies of Padang Lawas (Mid-Ninth Thirteenth Century CE). Paris: Cahier d'Archipel.

Rao, T. A. G. (1916). Elements of Hindu Iconography. Madras: The Law Printing House.

Restiyadi, A. (2010). Catatan Tentang Gaya Seni Relief di Candi Simangambat, Kabupaten Mandailing Natal, Provinsi Sumatera Utara. Sangkhakala, XIII NO. 2.

Restiyadi, A., Soedewo, E., Damanik, E. L., Nisa, K., \& Situngkir, B. (2011). Penelitian Situs Dunia di Sumatra Utara: Situs Candi di Padang Lawas: Tinggalan Arkeologi masa Hindu-Buddha di Kabupaten Padang Lawas dan Padang Lawas Utara, Provinsi Sumatra Utara. Medan: Museum Negeri Provinsi Sumatera Utara.

Schnitger, F. M. (1936). Oudheidkundige Vondsten in Padang Lawas. Leiden.

Schnitger, F. M. (1937). The Archaeology of Hindoo Sumatra. Leiden: E. J Brill.

Sedyawati, E., Santiko, H., Djafar, H., Maulana, R., Ramelan, W. D. S., Wurjantoro, E., \& Utomo, B. B. (2014). Candi Indonesia II: Seri Sumatera, Bali, Kalimantan, Sumbawa. Jakarta: Direktorat Pelestarian Cagar Budaya dan Permuseuman, Direktorat Jenderal Kebudayaan, Kementerian Pendidikan dan Kebudayaan.

Siregar, S. M. (2016). Jejak Tantrayana di Situs Bumiayu. Naditira Widya, Vol 10, $13-$ 24.

Soekmono. (1974). Candi Fungsi dan Pengertian. Universitas Indonesia.

Stein, D. L. (2018). Temple as Ritual Center: Tenth-Century Traces of Ritual and the Record in Stone. In The Hegemony of Heritage: Ritual and the Record in Stone. California: University of California Press.

Susetyo, S. (2010). Kepurbakalaan Padang Lawas, Sumatera Utara: Tinjauan Gaya Seni Bangun, Seni Arca, dan Latar Keagamaan. Universitas Indonesia.

Susetyo, S. (2014). Makara Pada Masa Sriwijaya. Kalpataru, 23(2), 101-112.

Taim, E. A. P. (2010). Simangambat, Candi Hindu Di Sumatera Utara. Sangkhakala, Vol $13,32-41$.

Vajhacharya, G. V. (2014). Kirtimukha, The Serpenting Motif, and Garuda: A Story of A Lion That Turned Into a Big Bird. Artibus Asiae, Vol 74, 311-336.

Van Eerde, J. C. (1911). Hindu-Javaansche en Balische Eeredienst. Bijdragen tot de Taal-, Land-en Volkenkunde, Vol 63, 1-39.

Vogler, E. . (1949). De Monsterkop: Uit Het Omlijstings ornament van Temple door gangen en-nissen. Leiden: E.J Brill. 